\title{
Komunikasi sebagai Wacana
}

\author{
Ibnu Hamad
}

ABSTRACT

\begin{abstract}
The purpose of this article is to describe communication as discourse perspective. In this perspective communication is seen an activity to construct of reality into a discourse that some interests entering the discourse. The perspective is to complete to the others ones, first transmissions perspective. Communication is to transmit of messages linearly. Second, perspective of display. Communication is an effort to exhibit many messages for gaining audiences attention.

Third, generating of meaning perspective where we use symbols to create meaning.

Fourth, ritual perspective which communication as a rites to maintain commonness and solidarity of the participants.
\end{abstract}

Kata kunci: wacana, perspektif ritual, konstruksi sosial

\section{Pendahuluan}

Sebagai sebuah bidang kajian, ilmu komunikasi terus mengalami perkembangan, baik menyangkut teori, metode penelitian, maupun dari aspek praktis. Sebagai contoh, dalam bidang teori, EM-Griffin (2003 : 21-36) menguraikan tujuh tradisi dalam teori komunikasi berdasarkan bidang kajian (seven tradition in the field of communication theory) sosio-psikologis, sibernetik, retorik, semiotik, sosio-kultural, kritikal, dan fenomenologi. Sedangkan Fisher (1986) mengajukan empat perspektif dalam teori komunikasi berdasarkan cara kerja: mekanistis, psikologis, interaksional, dan pragmatis.

Teori-teori komunikasi juga sering dilihat dari segi topik (topics in communication theory) seperti dilakukan Littlejohn (1999 : 39-225): teori sistem, tanda dan bahasa, wacana (discourse), produksi pesan, proses dan penerimaan pesan, interaksionalisme simbolik, dramatisme, dan naratif, realitas sosial dan budaya, pengalaman dan interpretasi, dan teori kritis. Adapula yang melihat teori komunikasi dari topik dan levelnya, sebagaimana dikerjakan Heath dan Bryant (2000): bahasa, makna, dan pesan, informasi dan ketidakpastian, persuasi, komunkasi interpersonal, komunikasi organisasi, dan komunikasi massa.

Tanpa menghilangkan tradisi kuantitatif(survey dan analisis isi kuantitatif) dan tradisi kualitatif yang lebih dahulu berkembang, dalam dekade 90an metode penelitian komunikasi diperkaya dengan analisis wacana (discourse analysis). Sebagai permulaan, Krippendorff (1980) memperkuat analisis isi kuantitatif dengan kajian tentang indeks dan simptom serta representasi linguistik dari isi media di mana aspek-aspek ini di kemudian hari menjadi pembahasan dalam analisis wacana. Kemudian, Berger (1982) menyediakan teknikteknik analisis media (media analysis techniques) yang sama sekali beda dari analisis isi. Ia membahas empat teknik analisis media : semiological analysis, marxist analysis, psychoanalityc critism, dan sociological.

Akhirnya, di pertengahan 90-an, analisis wacana 
berkembang pesat, termasuk di Indonesia. Kehadiran buku-buku yang berkenaan dengan wacana antara lain dari Fairclough (1995a dan 1995b), Mills (1997), Gee (1999, 2005) dan Titscher dkk (2000) serta penerbitan buku di dalam negeri seperti Sobur (2001), Eriyanto (2001), dan Hamad (2004), memperkuat metode dan pelaksanaan riset dengan memakai analisis wacana, baik sebagai analisis teks maupun sebagai analisis wacana kritis (critical discourse analysis) di Program Strata-1, Strata-2, dan Strata-3 Ilmu Komunikasi, bahkan dalam dunia praktis terutama bidang humas korporasi.

Berkenaan dengan praktik komunikasi, dewasa ini masyarakat, terutama para pelaku komunikasi dari media massa, humas, dan periklanan, cenderung menggunakan teknik pengemasan pesan (message packaging) demi memperoleh tujuan-tujuan komunikasinya. Mereka tak lagi sekadar membuat, menampilkan, dan mengirimkan pesan berdasarkan apa yang diingininya, tetapi merancang pesan dengan dilandasi dan dipengaruhi oleh "visi dan misi strategis"-nya sekaligus mengirimkannya kepada khalayak melalui cara dan taktik yang sangat persuasif. Dalam konteks ini, mereka mengembangkan suatu wacana tertentu jika bermaksud menyampaikan pesan kepada khalayak. Sekarang ini, kesadaran wacana memang cenderung bertambah bukan saja di pihak yang memproduksi pesan tetapi juga di pihak yang menerima pesan.

Semua perkembangan ini tentu saja mengharuskan kita menata kembali cara pandang kita terhadap pendekatan komunikasi. Bahwasanya dari segi caranya pesan dikelola terdapat satu pendekatan lain dari komunikasi. Itulah dia perspektif komunikasi sebagai wacana (communication as discourse). Perspektif ini bolehlah dikatakan melengkapi empat perspektif yang telah ada sebelumnya, yaitu: transmisionis, display, generating of meaning, dan ritual. Berikut ini adalah penjelasan satu persatu kelima perspektif tersebut.

\section{Perspektif Transmisionis}

Perspektif transmisionis merupakan pandangan yang paling dikenal dan paling dasar dalam komunikasi. Pandangan ini menekankan pada pengiriman pesan dari sumber ke penerima melalui suatu saluran tertentu dengan suatu efek (McQuail, 1994 : 51). Komunikasi dianggap sebagai proses penyampaikan pesan yang relatif lancar tanpa hambatan. Proses komunikasi dipandang berjalan secara linier, satu arah. Fiske (1990: 6-38) memasukkan model-model komunikasi dari Shannon-Weaver, Gerbner, Lasswell, Newcomb, Westley-MacLean, dan Jakobson ke dalam kelompok ini.

Betapa liniernya komunikasi itu, terutama dapat dilihat dalam model Lasswell, yang melihat komunikasi sebagai siapa mengatakan apa melalui saluran yang mana kepada siapa dengan efek apa." Dalam model ini, komunikasi digambarkan sebagai proses yang sangat lancar. Begitu seorang sumber (siapa) mengirimkan pesan (mengatakan apa) melalui sebuah media (melalui saluran yang mana) kepada penerima (kepada siapa) maka akan muncul efek (dengan efek apa). Dalam model ini, tidak diperhitungan karakteristik masing-masing komponen komunikasi. Tidak dipertimbangkan siapa komunikator yang lebih cocok untuk berbicara dengan penerima yang berbeda-beda latar belakang sosio-kultural dan psikologisnya. Juga tak dibicarakan saluran apa yang sebaiknya dipergunakan untuk menjangkau aneka jenis khalayak. Begitu pula dengan soal efek komunikasi, seakan-akan komunikasi akan selalu memberi hasil yang positif sesuai yang diharapkan.

Memang dalam model Shannon-Weaver diperhitungkan aspek gangguan (noise), namun tak menghilangkan sifat transmionisnya. Gangguan - baik gangguan teknis, semantis, dan humanis - itu justru sesuatu yang harus diatasi supaya pengiriman pesan berjalan dengan lancar.

Perspektif transmisionis memang melihat komunikasi secara mekanistik, ibarat upaya menyalurkan arus listrik dari sumbernya ke bolabola lampu dan atau alat-alat elektronik lainnya melalui kabel. Begitu alat-alat itu memperoleh arus listrik langsung menyala. Padahal, komunikasi manusia tidaklah bersifat mekanistik. Jika alat-alat itu tak menyala, berarti ada noise; dan gangguan inilah yang akan segera diperbaiki.

Dewasa ini masih banyak orang yang memakai pendekatan transmisionis, terutama di kalangan 
orang-orang yang merasa dirinya berkuasa sehingga menganggap khalayak hanya bertugas menerima apa pun yang ingin dikatakannya. Sebagai komunikator, mungkin ia menduga bahwa pembicaraanya pasti didengar dan menimbulkan efek kepada pendengarnya. Orang tua otoriter, pengajar yang masuk kategori old fashion, boss kantor yang totaliter, dan pemerintah yang despotik sangat menggemari perspektif ini.

\section{Perspektif "Display"}

Dalam perspektifini, komunikasi adalah usaha memamerkan sejumlah pesan guna menarik perhatian khalayak. Komunikasi dianalog kan dengan kegiatan pedagang memajang barangbarang dagagannya di etalase toko mereka. Dalam perspektif ini, komunikasi didayagunakan untuk menampilkan sebanyak mungkin pesan atau informasi untuk menarik perhatian khalayak (McQuail dan Windahl, 1993: 56-57; McQuail, 1994: 52). Pembuatan CV (curriculum vitae) atau daftar riwayat hidup merupakan contoh yang baik penggunaan perspektif display ini. Maklum, dalam $\mathrm{CV}$, segala informasi yang "penting" kita tuliskan agar pembaca tertarik pada kita.

Perspektif ini dikenal pula dengan model publisitas, sebuah model komunikasi yang menekankan pentingnya usaha-usaha memberikan informasi kepada publik (publisitas) agar mereka menjadi tahu dan sadar akan adanya ide atau pesan yang kita ingin sampaikan. Selanjutnya, setelah tahu dan sadar diharapkan publik memahami dan menyukai kita. Petugas humas seringkali melakukan upaya publisitas ini, antara lain melalui pembuatan press release atau press conferences

\section{Gambar 1 : Elemen Makna Peirce}

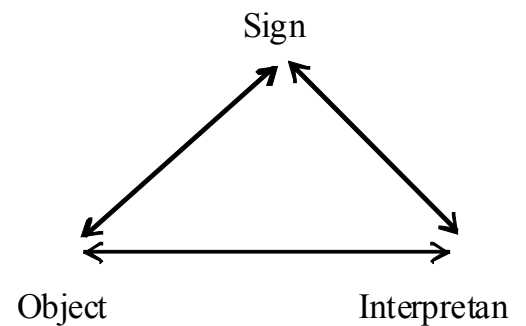

untuk mendisplay kinerja insitusinya di hadapan publik. Jika kita melihat halaman demi halaman koran, majalah, dan tobloid, semuanya bersifat mendisplay informasi agar masyarakat tertarik lalu membacanya.

Jadi, berbeda dari perspektif transmisionis yang mementingan pengiriman pesan, perspektif display mengutamakan hasil dari komunikasi berupa perhatian (attention) dari khalayak. Hasil di sini tiada lain adalah perhatian. Model displayattention atau model publisitas ini biasanya dicirikan oleh tiga hal: (1) perhatian umumnya hanya diberikan kepada hal-hal tertentu saja, dan tidak dapat dibagikan kepada hal-hal lain. Pengiriman pesan hanya sekadar memperoleh perhatian sehingga hasil dari proses komunikasi tidak dapat diukur; (2) perhatian dipusatkan pada masa sekarang. Masa depan tidak diperhitungkan kecuali sekadar kelanjutan dan pengembangan masa sekarang. Masa lalu sama sekali tidak diperhitungkan; dan (3) perolehan perhatian merupakan tujuan yang berdiri sendiri dan tidak memiliki tujuan instrumental (khusus) lainnya. Sehingga, perolehan perhatian dapat dipandang sebagai proses yang bernilai netral.

\section{Perspektif Mencipta Makna}

Komunikasi dengan perspektif menciptakan makna (generating of meaning) bertujuan menghadirkan makna tertentu di benak khalayak. Maksud seseorang berkomunikasi bukanlah mengirimkan pesan semata, tetapi yang lebih esensial adalah hendak menanamkan makna tertentu dalam pikiran penerima. Karenanya, pilihan tanda (signs) dalam komunikasi menjadi sangat

Gbr 2 : Semantic Triangle Richard

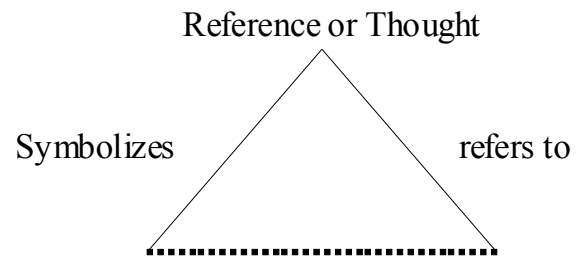

Symbol

Referent 
mendasar agar makna yang kita kirimkan dapat dipahami oleh khalayak (Fiske, 1990 : 39-63).

Pentingnya pilihan tanda dalam mencipta makna lazimnya dijelaskan oleh teori segi tiga makna atau tri-angle meaning theory (lihat Gambar 1 dan Gambar 2). Menurut teori ini, makna adalah hasil dari proses pertemuan antara penggunaan tanda yang merujuk pada obyek (yang ditandai) dan akal pikiran yang mencerna tanda tersebut. Makna yang muncul akan berbeda (berubah) jika tanda yang digunakan juga berbeda (berubah).

Dalam khazanah ilmu komunikasi, masalah penggunaan tanda dan maknanya ini dibahas oleh semiotika. Menurut semiotika, tanda (signs) terdiri dari ikon (icons) yang dicirikan oleh kemiripan seperti foto wajah seseorang mirip dengan pemilik wajah tersebut; indeks (index) yang dicirikan oleh keterkaitan seperti asap menandakan ada api; dan simbol (symbol) yang dicirikan oleh kesepakatan seperti "lampu merah" disepakati dengan berhenti; semua makna kata-kata adalah hasil kesepakatan (Berger, 2000)

Oleh karena setiap tanda cenderung memiliki makna yang berbeda-beda, apalagi jika dikaitkan dengan konteksnya, maka menurut perspektif ini penggunaan tanda (ikon, indeks, simbol) harus dipertimbangkan secara cermat sesuai dengan makna yang hendak diciptakan. Apalagi jika hal ini dikaitkan dengan pengembangan posisioning produk (untuk dunia pemasaran) dan citra lembaga (untuk dunia public relations).

Itulah sebabnya kita dapat memahami mengapa dunia pemasaran umumnya dan periklanan khususnya, paling banyak memakai perspektif komunikasi yang satu ini. Dalam rangka menciptakan posisioning suatu produk, mereka memilih bentuk, logo, dan merek produk tertentu. Mereka hanya menggunakan tanda termasuk gambar, kata, kalimat, lagu, dan musik yang dianggap mewakili selera target pasar mereka. Para pengiklan menyadari betul bahwa komunikasi pemasaran tidaklah dimaksdukan sebatas mengirimkan pesan tentang adanya produk, melainkan lebih ditujukan untuk menanamkan makna tertentu di benak khalayak mengenai produknya tersebut.

Demikian pula kita juga melihat dalam dunia sosial politik. Setiap orsos, ormas, dan parpol berijtihad memilih tanda yang paling representatif untuk organisasinya. Bukan saja bentuk logo atau lambangnya yang dipertimbangkan, melainkan juga warna, slogan, dan atribut lainnya. Semua ini dilakukan untuk membangun posisioning dan citra lembaga di mata khalayak.

\section{Perspektif Ritual}

Ibarat sebuah ritus (kegiatan ibadah), komunikasi dalam perspektif ritual dilakukan untuk memelihara kebersamaan dan solidaritas komunitas. Para partisipan dalam komunikasi dilibatkan agar menjadi bagian komunitas yang merasa saling memiliki, menjadi "jama'ah" dari komunitas tersebut. Kegiatan komunikasi (penggunaan pesan) adalah untuk berbagi (sharing), partisipasi, asosiasi, persahabatan (fellowship), memelihara keyakinan yang sama (the possesssion of common faith).

Tokoh komunikasi ritual, James W. Carey (1989:13-36) memberikan ciri-ciri komunikasi ritual sebagai berikut: (1) Komunikasi dikaitkan dengan terminologi-terminologi seperti berbagi (sharing), partisipasi (participation), asosiasi (association), persahabatan (fellowship), memiliki keyakinan yang sama (the possession of common faith); (2) Komunikasi dalam pandangan ini, tidak diarahkan untuk menyebarluaskan pesan melainkan ditujukan untuk memelihara (to maintenance) satu komunitas dalam suatu waktu; (3) Komunikasi dalam pandangan ini tidak diarahkan untuk memberikan informasi melainkan untuk menghadirkan kembali kepercayaan bersama; (4) Proses komunikasi dalam pandangan ini diibaratkan dengan upacara suci (sacred ceremony) di mana setiap orang berada dalam suasana persahabatan dan kebersamaan; (5) Penggunaan bahasa dalam komunikasi ritual tidak disediakan untuk kepentingan informasi tetapi untuk konfirmasi (peneguhan nilai komunitas); tidak untuk mengubah sikap atau pemikiran, tapi untuk menggambarkan sesuatu yang dianggap penting oleh sebuah komunitas; tidak untuk membentuk fungsi-fungsi, tetapi untuk menunjukkan sesuatu yang sedang berlangsung dan mudah pecah dalam 
sebuah proses sosial; (6) Dalam model komunikasi ritual, seperti dalam upacara ritual komunikan diusahakan terlibat dalam drama suci itu, tidak hanya menjadi pengamat atau penonton; (7) Oleh karena itu (poin 6), agar komunikasi ikut larut dalam proses komunikasi maka pemilihan simbol komunikasi hendaknya berakar dari tradisi komunitas itu sendiri, seperti hal-hal yang unik, yang asli, dan yang baru dari mereka.

McQuail dan Windahl (1993:54-55) dan McQuail (1994:50-51) memberikan ciri-ciri komunikasi ritual dengan: (8) Komunikasi ritual atau komunikasi ekspresif bergantung pada pengertian dan perasaan bersama. Komunikasi ini bersifat merayakan (celebratory), menikmati (consummatory) dan menghias (decorative); (9) Pesan yang disampaikan dalam komunikasi ritual biasanya bersifat tersembunyi (laten) dan bermkana ganda (ambigu), tergantung pada hubungan dan simbol yang tersedia dalam sebuah kebudayaan, bukan simbol yang dibuat oleh partisipan komunikasi; (10) Medium dan pesan dalam komunikasi ritual umumnya susah dipisahkan. Artinya, medium itu sendiri bisa menjadi pesan, karena bagi sebuah kebudayaan medium itu bisa memiliki makna tertentu; dan (11) Simbol dalam komunikasi ritual ini berfungsi sebagai simbolisasi untuk ide-ide dan penilaian atas keramah-tamahan, perayaan, dan persahabatan. Jadi, bukan menjadi alat untuk tujuan tertentu.

Jadi, jelaslah bahwa dalam komunikasi ritual penggunaan pesan lebih dimaksudkan untuk memelihara suatu komunitas, bukan untuk sekadar disebarluaskan. Penyebaran pesan tidak sebatas untuk memberikan informasi melainkan untuk menghadirkan kembali kepercayaan bersama. Konsekuensinya adalah simbol-simbol komunikasi harus berakar dari tradisi komunitas itu sendiri. Cara penyampaian pesan harus bersifat tidak langsung melainkan bersifat tersamar (laten) dan penuh makna (ambigu). Bahkan medium dan pesan susah dipisahkan, karena bagi sebuah komunitas acapkali medium itu adalah pesan.

Dalam paguyuban-paguyuban tradisional, pendekatan ini masih sering dipakai. Dalam kelompok-kelompok solidaritas, karena alasan psikografis apa pun seperti agama, ideologi, gaya hidup, secara sadar atau pun tak sadar pendekatan ini pergunakan. Komunikasi difungsikan untuk menjaga kebersamaan dan solidaritas kelompok. Sebuah perusahaan atau institusi yang memiliki corporate culture yang mapan dan egaliter umumnya juga menggunakan teknik komunikasi ritual ini untuk menciptakan iklim komunikasi yang produktif.

Di tengah heterogenitas masyarakat Indonesia, baik atas dasar ciri fisik (ras), suku (etnis), budaya (culture), status sosial ekonomi dan agama (religion), seharusnya pendekatan dipergunakan untuk menciptakan integrasi sosial bangsa. Apalagi Indonesia sedang berjuang keras menjadi negara yang demokratis yang mensyaratkan semua stakeholder bangsa ini setara, sehingga pendekatan ritual pastinya akan sangat menunjang bagi tercapainya cita-cita masyarakat madani.

\section{Komunikasi sebagai Proses Konstruksi Realitas}

Komunikasi dalam pandangan ini dilakukan dalam rangka menciptakan "kenyataan lain" atau "kenyataan kedua" melalui pembentukan sebuah wacana (discourse) sebagai "pengganti" dari realitas atau kenyataan pertama. Cara yang ditempuh dalam pembentukan wacana itu adalah suatu proses yang disebut konstruksi realitas atau construction of reality (lihat juga Gambar 3), sehingga realitas yang telah diwacanakan itu bolehlah kita sebut dengan realitas yang telah dikontruksikan (constructed of reality).

Berdasarkan sebuah penelitian (Hamad, 2004), proses konstruksi realitas oleh pelaku (2) dimulai dengan adanya realitas pertama berupa keadaan, benda, pikiran, orang, pristiwa, dan sebagainya (1). Secara umum, sistem komunikasi adalah faktor yang memengaruhi sang pelaku dalam membuat wacana. Dalam sistem komunikasi libertarian, wacana yang terbentuk akan berbeda dalam sistem komunikasi yang otoritarian. Secara lebih khusus, dinamika internal dan eksternal (4) yang mengenai diri si pelaku konstruksi tentu saja sangat mempengaruhi proses kontruksi. Ini juga 
menunjukkan bahwa pembentukan wacana tidak berada dalam ruang vakum. Pengaruh itu bisa datang dari pribadi si pembuat dalam bentuk kepentingan idealis, ideologis, dan sebagainya maupun dari kepentingan eksternal dari khalayak sasaran sebagai pasar, sponsor, dan sebagainya (5).

Untuk melakukan konstruksi realitas,, pelaku konstruksi memakai suatu strategi tertentu (6). Tidak terlepas dari pengaruh eksternal dan internal, strategi konstruksi ini mencakup pilihan bahasa mulai dari kata hingga paragraf; pilihan fakta yang akan dimasukkan/dikeluarkan dari wacana yang populer disebut strategi framing, dan pilihan teknik menampilkan wacana di depan publik atau taktik agenda setting (7). Selanjutnya, hasil dari proses ini adalah wacana (discourse) atau realitas yang dikonstruksian (8) berupa tulisan (text), ucapan (talk), atau peninggalan (artifact). Oleh karena discourse yang terbentuk ini telah dipengaruhi oleh berbagai faktor, kita dapat mengatakan bahwa di balik wacana itu terdapat makna dan citra yang diinginkan serta kepentingan yang sedang diperjuangkan (9).

Dalam konteks inilah, kita dapat memahami pengertian discourse menurut Gee (2005 : 26). Ia membedakan discourse kedalam dua jenis: Pertama, "discourse" (d kecil) yang melihat bagaimana

\section{Gambar 3: Proses Konstruksi Realitas}

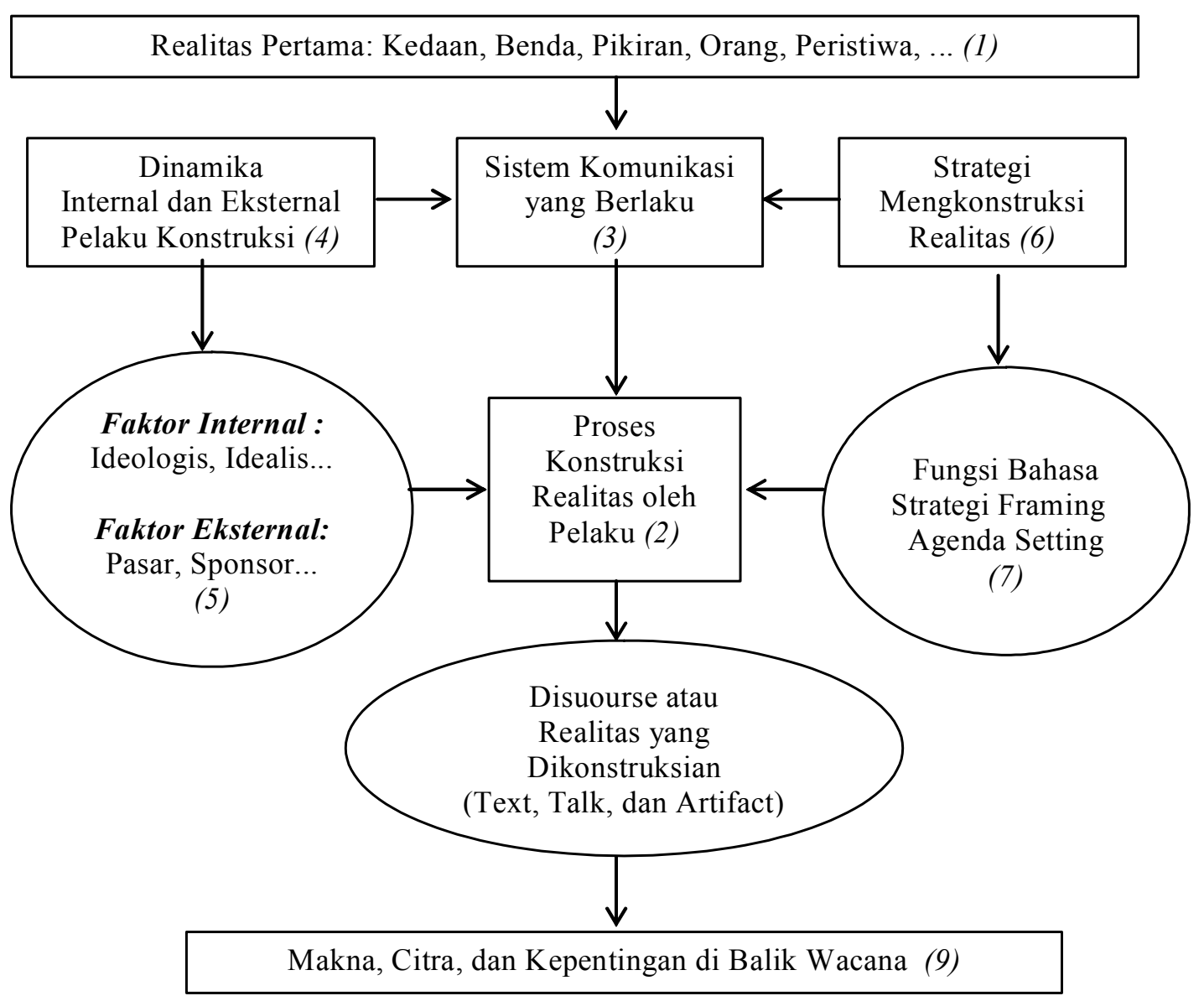


bahasa digunakan pada tempatnya (on site) untuk memerankan kegiatan, pandangan, dan identitas atas dasar-dasar linguistik. Kedua, "Discourse" (D besar) yang merangkaikan unsur linguistik pada "discourse" (dengan d kecil) bersama-sama unsur non-linguistik (non-language "stuff") untuk memerankan kegiatan, pandangan, dan identitas. Bentuk non-language "stuff" ini dapat berupa kepentingan ideologi, politik, ekonomi, dan sebagainya. Komponen non-language "stuff" itu juga yang membedakan cara beraksi, berinteraksi, berperasaan, kepercayaan, penilaian satu komunikator dari komunikator lainnnya dalam mengenali atau mengakui diri sendiri dan orang lain.

Jika kita memperhatikan kecenderungan komunikasi global dewasa ini, tampaknya perspektif communication as discourse inilah yang banyak dipergunakan. Negara-negara Barat cenderung membuat Discourse tentang dunia Islam. Bukan sekadar sebutan yang dipakai semisal terorisme, fundamentalisme, dan sejenisnya, opinion maker Barat acapkali mengonstruksikan Islam sebagai agama yang penuh dengan kekerasan, barbar, dan tidak humanis. Sebaliknya, mereka mewacanakan dirinya sebagai bangsa yang civilized, human right, dan demokratis.
Mungkin karena merasa bagian dari peradaban Baratnya, media Barat cenderung membentuk Discourse yang menyerang peradaban lain. Ketika Perang Dingin masih berlangsung ideologi komunislah yang terkena Discourse negatif guna membangun opini mengenai kejamnya komunisme (Herman dan Chomsky, 1992). Sedangkan pascaperang Dingin, khususnya setelah Tragedi 911, media Barat menjadikan Islam sebagai sasaran Discourse minor agar muncul opini betapa berbahayanya Islam.

Dari perspektif konstruksi realitas, tindakan komunikasi massa yang melibatkan pembuatan Discourse seperti dilakukan media Barat, atau media lainnya, dapat digambarkan oleh sebuah model komunikasi sebagai tampak dalam Gambar 4.

Dalam dunia politik, penggunaan Discourse ini lebih biasa lagi ,kalau bukan telah menjadi tradisi. Para aktor politik senantiasa menciptakan Discourse manakala mereka berbicara politik ( $p o-$ litical talks). Hal itu mereka lakukan bukan saja untuk kepentingan menyampaikan ideologi politik yang diyakininya, melainkan pula untuk menciptakan opini publik demi meraih keuntungankeuntungan politik yang ingin diperolehnya, entah itu kekuasaan, jabatan, ataupun material (Nimmo, 1978).

\section{Gambar 4: Model Konstruksi Realitas Untuk Komunikasi Massa}

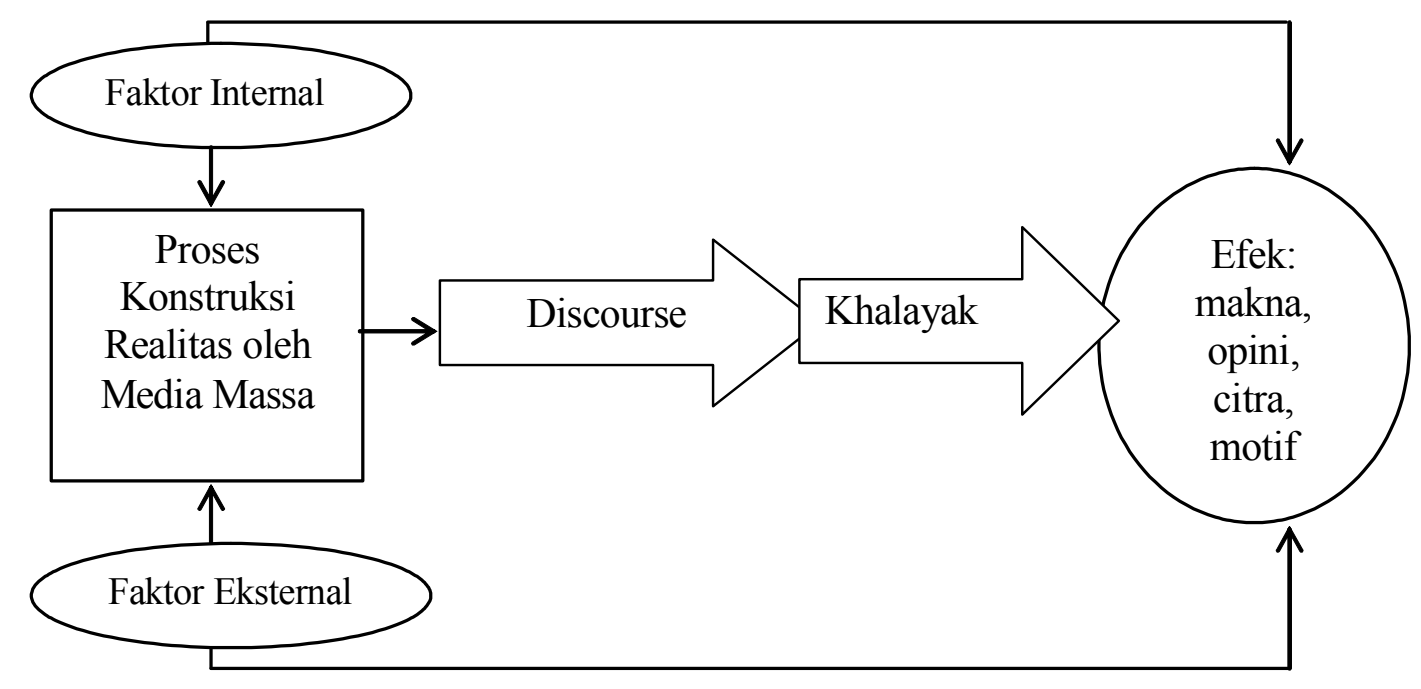


Tentu saja kalangan komunikasi pemasaran dan komunikasi pemasaran sosial amat menyukai pendekatan ini. Demi profit yang ingin didapat, para komunikator pemasaran menciptakan Discourse dengan cara memilih bahasa, fakta, dan taktik agenda setting. Begitu pula, untuk mengundang dukungan publik, para komunikator pemasaran sosial membentuk Discourse.

Sadar atau tidak, penceramah, instruktur, atau motivator juga suka mempraktikkan Discourse ini. Baik untuk kepentingan ideal maupun tujuan yang lebih pragmatis, mereka menggunakan Discourse untuk mempengarahi khalayaknya. Dibangunnya Discourse kebaikan untuk memberi kabar gembira; sebaliknya diciptakannya Discourse keburukan untuk menakut-nakuti khalayak.

Kalau ada dua individu berkeinginan mengembangkan hubungan, pastilah keduanya saling membuat Discourse yang mendukung pada perekatan hubungan mereka. Sebaliknya, jika mereka bermaksud memutus hubungan tentu keduanya, atau salah satunya, membangun Discourse yang merenggangkan hubungan mereka. Walhasil, peristiwa komunikasi seperti ini dapat digambarkan dengan s ebuah Model Komunikasi Konstruksi Realitas, seperti tampak dalam Gambar 5.

Nyata dari model ini (Gambar 5) bahwa komunikasi sebagai wacana dapat dimanfaatkan untuk kebaikan dan perdamaian, sebagaimana ia dapat disalah-gunakan untuk kejelekan dan peperangan. Seperti besi yang dapat dibuat peralatan tukang atau peralatan perang, demikian pula pesan dapat dibuat Discourse untuk kemanfaatan atau untuk kehancuran.

\section{Penutup}

Dari uraian di atas, setidaknya kita dapat menarik tempat implikasi. Pertama, implikasi pada khasanah teori komunikasi. Dengan adanya perspektifkomunikasi konstruksi realitas (communication as discourse), tentu saja menambah pemahaman kita tentang bentuk dan kegiatan komunikasi. Bahwasanya komunikasi tak hanya bersifat mengirimkan pesan, memajang sejumlah pesan untuk menarik perhatian, memanfaatkan simbol untuk menciptakan makna tertentu, atau membangun suasana kebersamaan. Komunikasi juga bersifat mengemas kepentingan dalam bentuk struktur pesan yang bermakna (discourse).

Implikasi pada strategi komunikasi. Untuk mencapai tujuan komunikasi tertentu, baik dalam komunikasi pemasaran maupun dalam komunikasi pemasaran sosial, para pengelola program komunikasi, tentu saja, memilih strategi komunikasi tertentu. Salah satu komponen dalam strategi komunikasi adalah penggunaan sebuah, atau lebih, pendekatan komunikasi. Yang perlu diingat, pilihan pendekatan komunikasi itu (walaupun bukan satusatunya yang memengaruhi) memiliki dampak pada

\section{Gambar 5: Model Komunikasi Konstruksi Realitas}

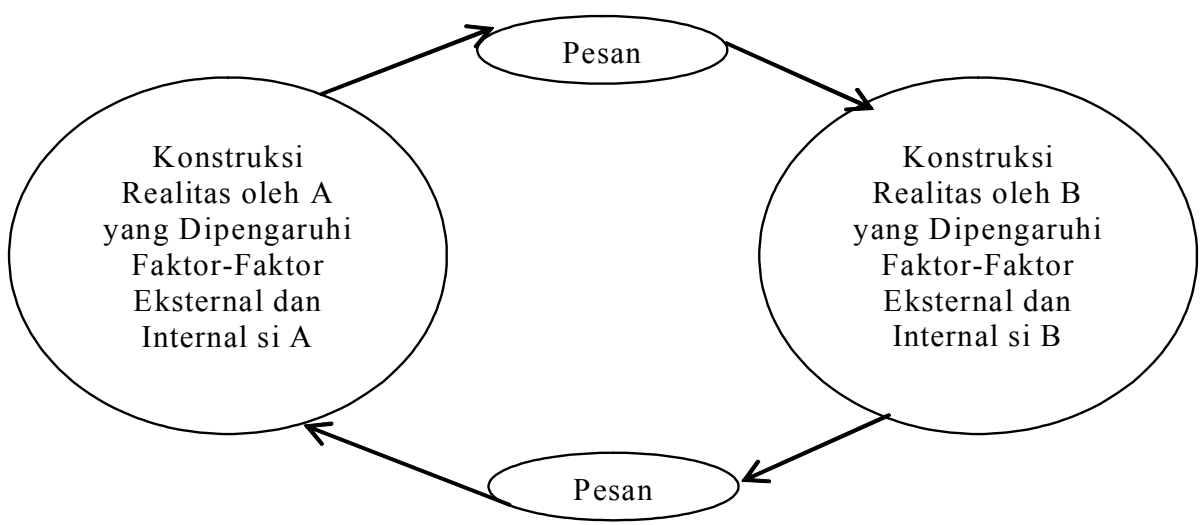




\section{Tabel 1. Efektivitas Tujuan Program Komunikasi berdasarkan Pendekatan Komunikasi}

\begin{tabular}{|l|c|c|c|}
\hline \multirow{2}{*}{ Pendekatan komunikasi } & \multicolumn{3}{|c|}{ Efek yang Ingin Dihasilkan } \\
\cline { 2 - 4 } & Kognitif & Afektif & Konatif \\
\hline Transmisionis & $\sqrt{ }$ & & \\
\hline Display & $\sqrt{ }$ & & $\sqrt{ }$ \\
\hline Mencipta Makna & & & $\sqrt{ }$ \\
\hline Ritual & & & \\
\hline Discourse & & & \\
\hline
\end{tabular}

efektivitas pada pencapai tujuan sebuah program komunikasi.

Sebagaimana tampak dalam Tabel 1, jika efek komunikasi secara umum dibagi atas tiga level, maka pendekatan transmisionis dan ritual cenderung lebih efektif untuk menghasilkan efek pada level kognitif. Pendekatan generating of meaning cenderung lebih efektif untuk efek konatif. Sementara efek konatif (psikomotorik) cenderung lebih efektifjika menggunakan pendekatan ritual dan konstruksi realitas.

Kehadiran ragam pendekatan komunikasi ini juga memberi implikasi pada metode penelitian komunikasi. Pendekatan konstruksi realitas menghidupkan metode analisis wacana (discourse analysis) untuk membongkar realitas di balik wacana; dan hal ini memberi pengayaan pada metode penelitian survei (untuk mengukur efektivitas penggunaan pendekatan transmisionis, display, generating of meaning, ritual atau discourse terhadap pencapaian tujuan progam komunikasi) dan metode penelitian etnografis atau fenomenologis -dua di antara metode penelitian dalam pendekatan kualitatif - (untuk menjelaskan penggunaan komunikasi ritual).

Akhirnya, perspektif communication as discourse ini memberi implikasi sosial. Kita dapat mendayagunakan Discourse untuk kebaikan pada level individu, kelompok, organisasi, sosial, dan global. Kita kurangi atau cegah konflik individu, sosial dan global melalui Discourse yang bersifat meredam kekerasan. Kita ciptakan dunia yang damai melalui pengembangan Discourse yang menyejukkan dan menentramkan.

\section{Daftar Pustaka}

Berger, Arthur Asa. 2000. Tanda-Tanda dalam Kebudayaan Kontemporer (terjemahan). Yogyakarta: Tiara Wacana.

Berger, Arthur Asa. 1982. Media Analysis Techniques. Beverly Hills: Sage Publication.

Carey, James W. 1989. Communication as Culture, Essays on Media and Society. Boston: Unwin Hyman

Crowly, David dan David Mitchell. 1994. Communication Theory Today. Cambridge: Policy Press.

Eriyanto, (2001). Analisis Wacana, Pengantar Analisis Teks Media. Yogyakarta: LKiS,

Fairclough, Norman. 1995a. Critical Discourse Analisis: The Critical Study of Language. London-New York: Longman.

Fairclough, Norman. 1995b. Media Discourse. London: Edward Arnold. 
Fisher, B. Aubrey 1986. Teori-Teori Komunikasi. Bandung: Remadja Karya.

Fiske, John, 1991. Introduction to Communication Studies. London and New York: Routledge.

Gamson, Willam A dan Andre Modigliani. 1998. "Media Discourse and Public Opinion on Nuclear Power A. Constructionist Approach," Journal of Sociology, Vol 95, No. 1. July.

Gee, James Paul. 2000. An Introduction to Discourse Analysis, Theory and Method. London - New York: Routledge.

Griffin, EM. 2003. A First Look at Communication Theory. Boston-Toronto: McGraw Hill.

Hamad, Ibnu. 2004. Konstruksi Realitas Politik di Media Massa sebuah Study Critical Discourse Analysis Discourse. Jakarta: Granit.

Heath, Robert L dan Jannings Bryant. 2000. Human Communication Theory and Research, Concepts, Contexts, and Challenges. Mahwah, New Jersey - London: Lawrence Erlbaum Associate Publisher.

Herman, Edward S and Noam Chomsky. 1992. Manufacturing Consent, The Political Economy of The Mass Media. New York: Pantheon Books.
Krippendorf, Klauss. 1980. Content Analysis, An Introduction to Its Methodolgy" (Beverly Hill California: Sage Publication.

Littlejohn, Stephen W. 1999. Theories of Human Communication. Belmont-Toronto: Wadsworth Publishing Company.

McQuail, Dennis. 1994. Mass Communication Theory. London-Thousand Oaks-New Delhi: Sage Publication.

McQuail, Dennis and Sven Windahl. 1996. Communication Models: for The Study of Mass Communication. New York: Longman.

Mills, Sara. 1997. Discourse, London and New York: Routledge

Sobur, Alex. 2001. Analisis Teks Media, Suatu Pengantar Analisis Wacana, Analisis Semiotik, dan Analisis Framing. Bandung: Rosdakarya.

Titscher, Stefan, at.al. 2000. Methods of Text and Discourse Analysis. London-Thousand Oaks-New Delhi: Sage Publication. 